\section{Sexuality and HIV prevention: consensus and dissent of Catholic youths}

\author{
Pablo Luiz Santos Couto' \\ Mirian Santos Paiva ${ }^{2}$ \\ Jeane Freitas de Oliveira ${ }^{3}$ \\ Antônio Marcos Tosoli Gomes ${ }^{4}$ \\ Marizete Argolo Teixeira ${ }^{5}$ \\ Elionara Teixeira Boa Sorte ${ }^{6}$
}

Sexuality and HIV prevention: consensus and dissent of Catholic youths

Objective. To analyze the consensus and dissent of Catholics youths about HIV/AIDS prevention from their representations about sexuality. Methods. This is a quantitative and qualitative research based on the Theory of Social Representations carried out with 84 Catholics youths who answered online to the Free Word Association Test on Facebook and three questions about the influence of Catholic doctrine on the free exercise of sexuality and the adoption of practice safe sex. The techniques of Factorial Analysis of Correspondence and Semantic Content were used. Results. On sexuality, only the young women with access to higher education represented the term as a free practice that should not lead to guilt. There was a consensus on chastity, virginity, and sex within marriage as effective means of HIV prevention. It is also representational consensus of the young people that sexual practice is pleasurable, however, condemned by the church, and that AIDS is a preventable disease. Social

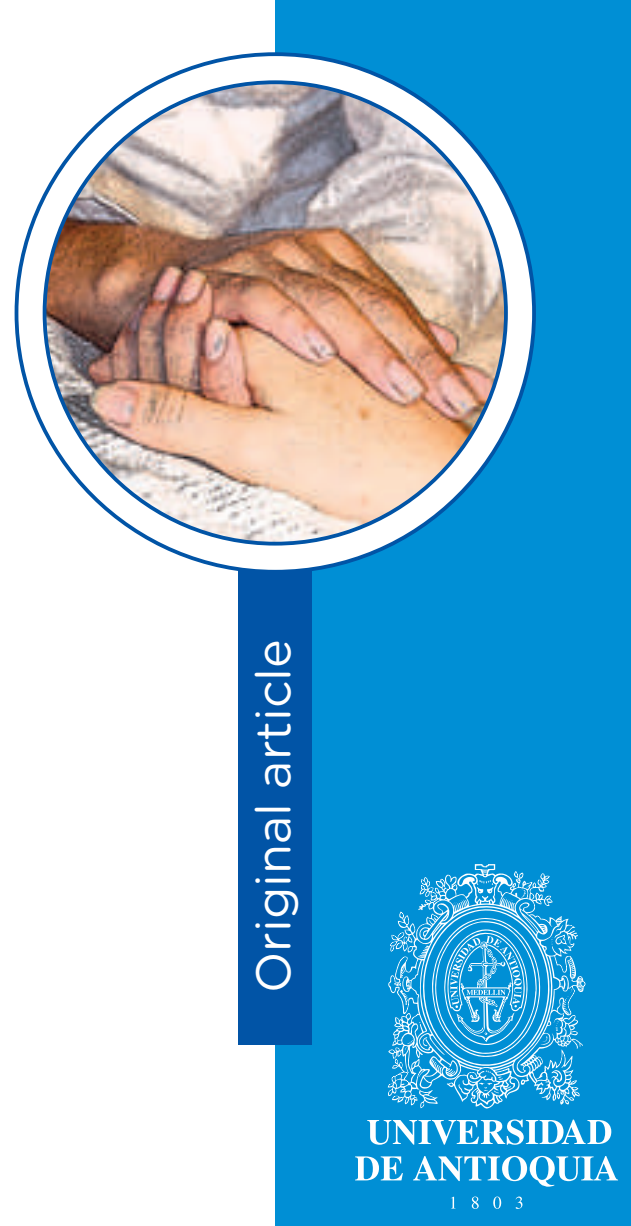

1 Nurse, Master degree. Professor, Faculdade Guanambi (Brazil).

email: pablocouto0710@gmail.com

2 Nurse, Ph.D., Professor. Federal University of Bahia (Brazil). email: paivamirian@hotmail.com

3 Nurse, Ph.D., Professor, Federal University of Bahia (Brazil). email: jeane.foliveira@outlook.com

4 Nurse, Ph.D., Professor, Federal University of Rio de Janeiro (Brazil).

email: mtosoli@gmail.com

5 Nurse, Ph.D., Professor, State University of South-west Bahia (Brazil).

email: marizete88@yahoo.com.br

6 Nurse, Master degree. Professor, Universidade do Estado da Bahia (Brazil).

email: naratbsorte@gmail.com

Research linked to the article: Social representations on the exercise of sexuality and HIV/AIDS prevention in young Catholic(s) girls.

Funding: Capes/CNPq - Master's Degree Scholarship.

Conflicts of interest: None.

Received: May $9^{\text {th }}, 2017$

Accepted: May $31^{\text {st }}, 2018$.

How to cite this article: . Couto PLS, Paiva MS, Oliveira JF, Gomes AMT, Teixeira MA, Sorte ETB. Sexuality and HIV prevention: consensus and dissent of Catholic youths. Invest. Educ. Enferm. 2018; 36(2):e06.

DOI: 10.17533/udea.iee.v36n2e06

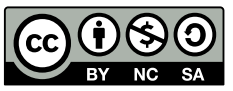


representations have revealed dissent between men and women, while they consider that the exercise of sexuality should be restricted to marriage, they advocate sexual freedom. As for AIDS, they represent that the syndrome stems from prejudice, and they consider that vulnerability favors contagion. Conclusion. In the consensuses among the young people studied, there are sexist prejudices and stereotypes that influence HIV/AIDS prevention actions. Therefore, health professionals, especially those of Nursing should propose actions aimed at this age group in educational activities about the adoption of preventive practices on safe sex, always considering the social representations around the subject.

Desciptors: young adult; religion and sex; sexuality; sexual behavior; consensus; dissent and disputes; acquired immunodeficiency; síndrome; social media.

\section{Sexualidad y prevención del VIH: consenso y disenso de jóvenes católicos}

Objetivo. Analizar los consensos y desacuerdos entre los jóvenes católicos sobre la prevención del VIH/SIDA a partir de sus representaciones sobre la sexualidad. Métodos. Investigación cuanti-cualitativa basada en la Teoría de las Representaciones Sociales. 84 jóvenes católicos respondieron on-line en Facebook un cuestionario de Asociación Libre de Palabras y tres preguntas sobre la influencia de la doctrina católica en el libre ejercicio de la sexualidad y en la adopción de prácticas sexuales seguras. Se utilizaron las técnicas de Análisis Factorial de Correspondencias y de contenido semántico. Resultados. Sobre la sexualidad, solamente los jóvenes con acceso a la educación superior, representaron el término como una práctica libre que no debe causar culpabilidad. Hubo consenso en cuanto a la castidad, la virginidad y el sexo dentro del matrimonio como medios eficaces para la prevención del VIH. También fueron consensos representacionales entre los jóvenes que la práctica sexual es placentera, sin embargo es condenada por la Iglesia, además, que el SIDA es una enfermedad que puede prevenirse. Las representaciones sociales revelaron disensos entre hombres y mujeres puesto que mientras que ellos consideraban que el ejercicio de la sexualidad debe ser restringido al matrimonio, ellas defendieron la libertad sexual. En cuanto al SIDA, ellos estiman que el síndrome deriva del prejuicio y ellas consideran que la vulnerabilidad favorece el contagio. Conclusión. En los consensos entre los jóvenes participantes del estudio hay preconceptos y estereotipos sexistas que influyen en las acciones de prevención del VIH/SIDA. Por tanto, los profesionales de la salud, en 
especial los de Enfermería, deben proponer que en las actividades educativas sobre la adopción de prácticas preventivas sobre sexo seguro que se realizan en este grupo etário se tengan en cuenta las representaciones sociales sobre el tema.

Descriptores: adulto joven; religión y sexo; sexualidad; conducta sexual; consenso; disentimientos y disputas; síndrome de inmunodeficiencia adquirida; medios de comunicación sociales; mídias sociais.

\section{Sexualidade e prevenção ao HIV: consensos e dissensos de jovens católicos}

Objetivo. Analisar consensos e dissensos de jovens católicos/as sobre a prevenção ao HIV/aids a partir de suas representações sobre a sexualidade. Métodos. Pesquisa quanti-qualitativa, fundamentada na Teoria das Representações Sociais, realizada com 84 jovens católicos, que responderam on-line no Facebook ao Teste de Associação Livre de Palavras e três questão acerca da influência da doutrina católica no livre exercício da sexualidade e na adoção de prática sexuais seguras. Foram utilizadas as técnicas de Análise Fatorial de Correspondência e de Conteúdo Semântica. Resultados. Sobre a sexualidade, apenas as jovens com acesso ao ensino superior representaram o termo como uma prática livre que não deve acarretar culpa. Houve consenso quanto a castidade, a virgindade e o sexo dentro do matrimônio como meios eficazes de prevenção ao HIV. Também são consensos representacionais entre os jovens que a prática sexual é prazerosa, entretanto condenada pela igreja e que a AIDS é uma doença que pode ser prevenida As representações sociais revelaram dissensos entre homens e mulheres, enquanto eles consideram que 0 exercício da sexualidade deve ser restrito ao casamento, elas defendem a liberdade sexual, quanto a AIDS eles representam que a síndrome decorre do preconceito, elas consideram que a vulnerabilidade favorece o contágio. Conclusão. Nos consensos entre os jovens estudados, há preconceitos e estereótipos sexistas que influenciam as ações de prevenção do HIV/Aids. Portanto, os profissionais de saúde, sobretudo os de Enfermagem, devem propor que, nas atividades educativas sobre a adoção de práticas preventivas sobre sexo seguro, ações voltadas para essa faixa etária, considerando sempre as representações sociais em torno ao assunto.

Descritores: adultos jóvenes; religião e sexo; sexualidade; comportamento sexual; consenso; dissidências e disputas; síndrome de imunodeficiência adquirida. 


\section{Introduction}

T

hroughout history, religious practices and their entire mystical, symbolic and magical dimension have become inherent to the human being by fomenting the formation of social representations. As various aspects of life are guided by religion, which influences both the origin of new ideas and categories of thought and reaffirms existing values, these same aspects tend to stimulate the development of religious practices in a circle of constant self-empowerment. ${ }^{(1)}$

In this sense, the Catholic Church has been a former of representations and meanings regarding everyday affairs, always with the intention of influencing the thoughts and ideas of social groups and individuals to preserve their practices and their characteristic values. Faced with the many facets that HIV prevention has in the discourses and practices that permeate the sexuality and daily life of society, there are several young people inserted and linked in the Christian Catholic religion, found in an ethical and bombarded crossroads by meanings disseminated by various spheres of society about what is right or wrong about the exercise of sexuality or sexual practice. ${ }^{(2)}$ Therefore, this study becomes relevant for the understanding of how young Catholics live sexuality and what preventive behaviors for HIV prevention are adopted. Therefore, it can contribute to educational actions developed by health professionals, especially by nurses, in constructing a care system that guides discussions about sexual health care. Also, this work has its relevance because there are few studies conducted on Facebook aimed at the sexual health of religious youths.

The Theory of Social Representations was the theoretical support adopted, since it allowed the understanding of social and mental constructions, as well as of the socio-cognitively constructed meanings, making it adequate for this study. The network of meanings, which is shared between individuals, brings them closer to forming the membership groups. ${ }^{(3)}$ In this aspect, this article discusses the contents that emerge from the cognitive field that originate the social representations of Catholic youths belonging to the Renewal The Catholic Charismatic Church, which maintains discourses consistent with Roman Catholic precepts, renewing the practice of rites and the mystique of the church. ${ }^{(4)}$ From this, to analyze the consensus and dissent of young Catholics about HIV/AIDS prevention from their representations about sexuality was the goal set for the development of this study.

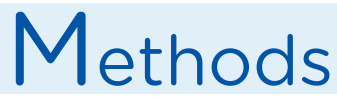

It is a quantitative-qualitative research, so it is a study with mixed methods and techniques, which uses the strengths of qualitative and quantitative research, helping to break with the positivist and interpretative paradigms, based on the Theory of Social Representations. Data were produced between 
February and March 2015 on the Internet, with 84 young Catholics aged between 18 and 24, of both genders, who participated in World Youth Day, members of the group in the social network called Facebook, which was constituted as a research scenario. In the selection of the participants, information was also considered to regularly attend a parish and to join one of the groups linked to the Catholic Charismatic Renewal. There was no need to apply exclusion criteria.

For the production of the data, three techniques were used, appropriate to the research based on the Theory of Social Representations, applied at different moments. The characterization questionnaire and the Free Word Association technique were answered by 84 participants, who agreed to contribute to the survey after being invited from a collective invitation to the youth who were members of the World Youth Day page on Facebook and had participated in the event in 2013. The participant identification/ characterization questionnaire was composed of the following variables: gender, age, city/state, education level, self-reported color, how often they went to church, participation in Catholic youth groups, sexual orientation, beginning of sexual intercourse, number of partners, condoms use during sexual activity. The stimuli used for the free association of words were: Exercise of sexuality; Exercise of sexuality and Catholic religion; AIDS; AIDS and Catholic religion. Finally, the questions used in the interviews and the sub-questions that made up the developments were: 1- From your experience and the exchange of information and knowledge within the Catholic group of which they belong, tell me about how it is seen and discussed the exercise of sexuality between you and how feel on this issue. 1.1- Still in relation to your experience in your group of belonging, tell me how you feel on the various sexual practices. 2The Catholic Church advocates sexual abstinence before marriage as a way to avoid unwanted pregnancy and infection by sexually transmitted diseases or HIV. Tell me how you feel in relation to sexual abstinence. 2.1. Comment your opinion on a young man who professes the Catholic faith, having multiple partners - regardless of sexual orientation - as a free form of the exercise of sexuality 3. Still based on the Catholic Church's speeches and what is discussed in your group, tell me about your vision of safe sex. 3.1- Discuss your opinion about condoms and AIDS and how this topic is discussed in your group. 3.2- Tell us a little about your position on the Catholic Church's internal policy regarding sexuality and AIDS prevention.

After the invitation, the 84 young people who agreed to participate in the production of information, responded online and instantly to an in-depth interview script in the social network's tool available for dialogue and exchange of information between people, known as "inbox" or simply "chat boxes", which contained the three guiding questions (apart from the questionings that unfolded during the interview) about the influence of Catholic doctrine on the free exercise of sexuality and the adoption of safe sexual practice. It is reiterated that the interview was developed online and individually, since the questionings were made one after the other, after each answer given by the participant, until the interviewer was satisfied with the information provided. This technique had the participation of 19 Internet users. The data obtained through the Theory of Social Representations were coded and organized in the Factorial Map of Correspondence originated by software Tri-Deux Mots version 2.2 and analyzed according to Factorial Matching Analysis. In turn, the verbalizations emanating from the in-depth interviews were copied from the "chat boxes" in full and then organized and analyzed according to the semantic similarity of the content of the speeches with the evocations, when it was possible to cross the answers with consequent identification of consensus and dissent.

In the factorial analysis of correspondence, variations of words were visualized in relation to the spatial organization of the evocations (opinion variables) for the inductors described above. The analysis showed approximations and distances of the fixed variables (gender, race, origin and education level) and the opinion variables in the two factors that conformed the factorial map. 
The research complied with all the steps recommended in Resolution 466/2012 of the National Health Council, approved by the Ethics and Research Committee of the Federal University of Bahia, protocol number 878.042/2014. The TCLE was sent online through the tools provided by the social network, and after reading, the participants confirmed their participation with the digital signature.

\section{Results}

The general characteristics of the 84 participants can be appreciated in Table 1. They were $51.2 \%$ man. About the age group, there was a certain balance between the number of participants, from 18 to 21 years old was $46.4 \%$ and from 22 to 24 years old was $53.6 \%$. Most of them came from the state of Bahia (42.8\%) followed by Minas (14.3\%). Regarding their education level, the upper level prevailed (38.1\%), with courses completed. Approximately half of the participants declared themselves as white (48.8\%) and the other half black/brown (51.2\%). Most reported being single (72.6\%). As for sexual orientation, $21.4 \%$ of the young people declare themselves as homosexual and $9.5 \%$ as bisexual. Regarding the practice of safe sex with a condom, $38(45.2 \%)$ did not use it (of them, 21 declare themselves virgins and 17 had unprotected sex). Of the total number of participants, $73.8 \%$ reported attending the church 2-3 times per week and $26.2 \%$ between 4 and 5 times.

Table 1. General characteristics of the 84 study participants

\begin{tabular}{lcc}
\multicolumn{1}{c}{ Characteristic } & Frequency & $\%$ \\
\hline Gender & & \\
\hline Male & 43 & 51.2 \\
\hline Female & 41 & 48.8 \\
\hline Age group (years old) & & \\
\hline $18-21$ & 39 & 46.4 \\
\hline $22-24$ & 45 & 53.6 \\
\hline Origin (States of the Federation of Brazil) & & \\
\hline Bahia & 36 & 42.8 \\
\hline Minas Gerais & 12 & 14.3 \\
\hline Rio de Janeiro & 7 & 8.3 \\
\hline São Paulo & 7 & 8.3 \\
\hline Ceará & 4 & 4.8 \\
\hline Pernambuco & 4 & 4.8 \\
\hline Rio Grande do Norte & 3 & 3.6 \\
\hline Goiás & 3 & 3.6 \\
\hline Paraíba & 2 & 2.4 \\
\hline Paraná & 2 & 2.4 \\
\hline Sergipe & 1 & 1.2 \\
\hline Mato Grosso & 1 & 1.2 \\
\hline Distrito Federal & 1 & 1.2 \\
\hline Pará & 1 & 1.2 \\
\hline
\end{tabular}


Table 1. General characteristics of the 84 study participants. (Cont.)

\begin{tabular}{|c|c|c|}
\hline Characteristic & Frequency & $\%$ \\
\hline \multicolumn{3}{|l|}{ Education } \\
\hline Complete Higher Education & 32 & 38.1 \\
\hline Incomplete higher education & 30 & 35.7 \\
\hline Complete high school & 22 & 26.2 \\
\hline \multicolumn{3}{|l|}{ Self-declared color } \\
\hline Black/brown & 43 & 51.20 \\
\hline White & 41 & 48.8 \\
\hline \multicolumn{3}{|l|}{ Marital status } \\
\hline Singles & 61 & 72.6 \\
\hline Married & 23 & 28.4 \\
\hline \multicolumn{3}{|l|}{ Sexual orientation } \\
\hline Heterosexuals & 58 & 69.1 \\
\hline Homosexuals & 18 & 21.4 \\
\hline Bisexuals & 8 & 9.5 \\
\hline \multicolumn{3}{|c|}{ Safe Sex Practice with a condom } \\
\hline They used & 46 & 54.8 \\
\hline They do not used & 38 & 45.2 \\
\hline Virgins & 21 & 55.2 \\
\hline Active sex life & 17 & 44.8 \\
\hline \multicolumn{3}{|c|}{ Frequency with which they went to church } \\
\hline 2-3 times per week & 62 & 73.8 \\
\hline 4-5 times per week & 22 & 26.2 \\
\hline
\end{tabular}

In the factorial analysis of correspondence, the total variance of the evocations was explained by the sum of the percentage values of the correlations emerged with the processing of the data by the software Tri-Deux Mots (Figure 1), a total of $63.5 \%$, which demonstrates reliability of the statistical parameters (considering the qui $^{2}$ analysis possible by the factorial analysis of correspondence), consistency of the answers, enabling a significant analysis. For this study, the minimum frequency of 8 words was considered due to the plurality of the semantic field elaborated by the participants; 1637 words were evoked for 4 stimuli, 313 of which were different.

The stimulus that offered the greatest contribution of words to the game of oppositions was stimulus 3 (AIDS), possibly due to its greater diffusion, propagation, and propaganda, in the media and social environments. Gender, age, and race were the fixed variables with the highest contribution. When correlating the variable gender with the variables of opinion, there was dissent in the formation of the representations. Thus, the opposition of men and women of black race in the age group of 22 to 24 years old, and of young white men from 18 to 21 years old was noticed.

It was also evidenced that the men in the formation of the representations did not express statistically significant evocations for the stimulus1 (e1) exercise of sexuality, possibly demonstrating the traumatic character of the stimulus for these youths. However, as they were stimulated by the increased expression of the Catholic religion, stimulus2 (e2), they verbalized the words repression, sin, respect, 
and doctrine, revealing the psychological defense of the sexual control exercised by the church.

The talk of the participants ratifies these objections: (...) I think and understand the purpose of the church and I think it is a conscious attitude, it only wants to protect the young, teaching that premarital sex can generate bad consequences such as unwanted pregnancy, diseases [E.3; male]. The stimulus Aids (e3) was objectified in the words irresponsibility and prejudice, in turn, when stimulated by Catholic religion and AIDS (e4) they mentioned doctrine. They presented consensuses in the representations for these stimuli. The following statements relate to the elaborate evocations: I agree with the Catholic Church, because it gives indications consistent with the Bible, and it is the truth. We must believe in it, for the things and illnesses that take place in the world are due to people who do not follow what the mother church teaches [E.10; male]. Safe sex for us is within marriage. In marriage, there is security. But if one partner has STDs they will have to use a condom because it is only allowed for couples, where one partner has contracted AIDS or other STDs [E.18; male].

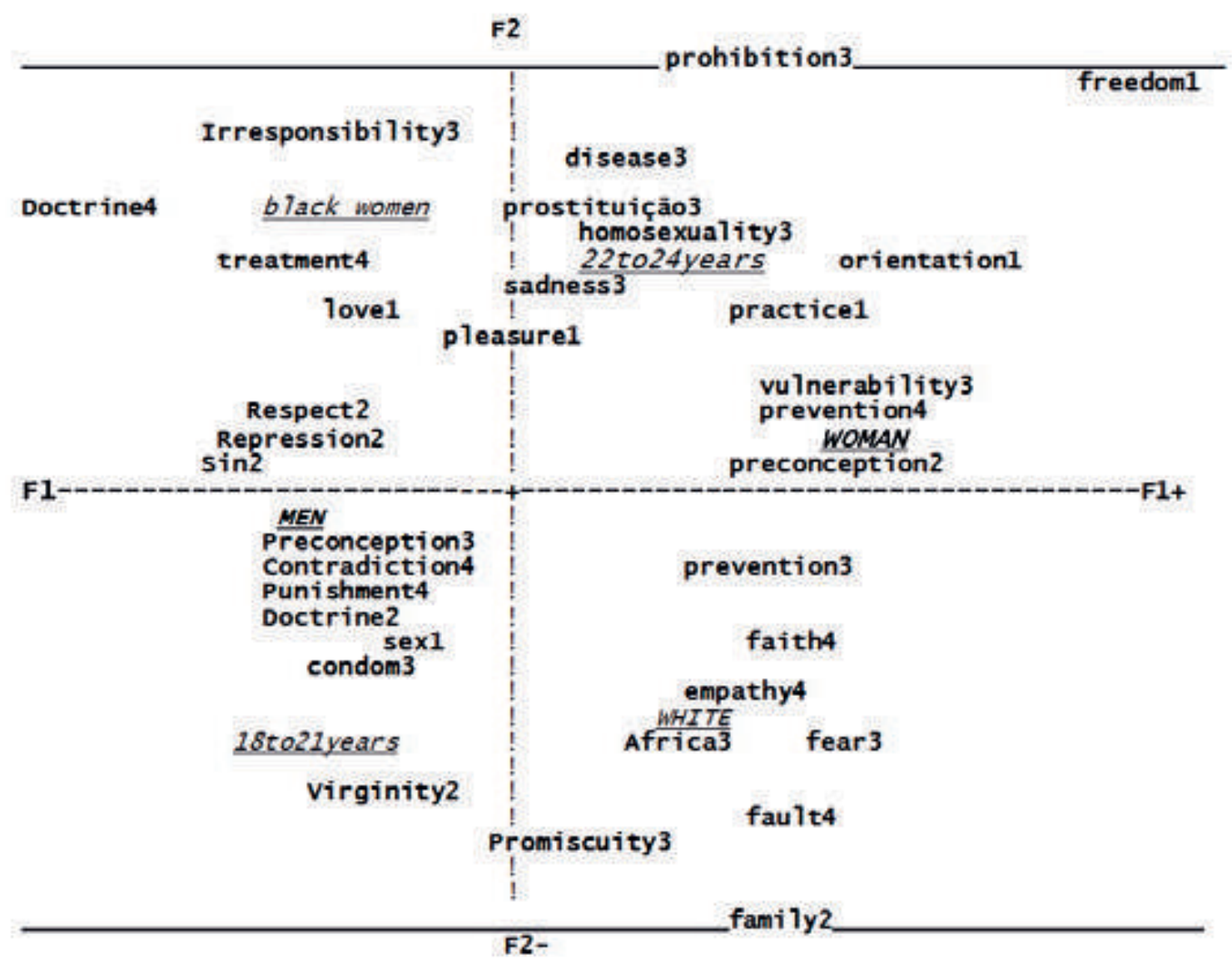

Figure 1. Factorial plan for Correspondence Factor Analysis. F1 Fixed variable contributors: F1 + Young women, F1- Young men; F2 Contributing fixed variables: F2 + Blacks between 22 to 24 years old, F2- Whites between 18 to 21 years old) 
In dissonance of the men, the women evoked for the (e1) the exercise of the sexuality the words orientation and practices (sexual). For the stimulus 2, Catholic religion and exercise sexuality issued bias. Excerpts from the interviews of some participants reinforce these representations: We talk about sexuality, but it is not profound, everything very superficial... and what we have to do is resist, I have been struggling to resist all this, sometimes I can (...) but like all sin, I try to resist even though it is difficult [E.4; women]. I have another view... since the church forbids certain positions on diversity in sexual practice... the Catholic did not adapt to the modern world where sex has become commonplace [E.17; women].

When asked about the stimulus3 (e3) AIDS, they represented the terms vulnerability, fear, and prevention. When stimulated by the expression catholic religion and AIDS (e4) they once again referred to the prevention, this time, associating the Catholic principles (chastity, marriage) in the prevention of HIV infection. The contents obtained in the participants' answers complement the words objectified: (...) The condom is an ally in the prevention of diseases and AIDS mainly because it is a serious disease (...) but for the sex after the marriage is not required. I prefer fidelity [E. 1 ; women].

Young people between 18 and 21, who declared to be black, objectified pleasure, freedom, love for the stimulation of sexuality; and the word forbidden to (e2), catholic religion and exercise of sexuality. My position on sexuality is of total respect. People should choose their sexual practice (...) I understand the exercise of sexuality as freedom of choice to practice and with whom to practice [E.14; young black woman; 22 years]. Our dogmas teach us to live sex with the beloved (...) The church teaches to live chastity. Chastity is to live with the loved one, the church teaches it ... Chastity is you living the relationship with only the person you truly love [E.19; young black woman; 24 years].

When stimulated by the word AIDS (e3) they verbalized disease, irresponsibility, homosexuality, prostitution, treatment, and sadness. However, they did not emit any evocation for the expression catholic religion and AIDS (e4), possibly because they blocked the association between the terms of their networks of cognition. The following statements reinforce the representations also expressed in the evocations: AIDS is a very sad disease and causes a lot of suffering (...) the condom has a problem, that despite the many campaigns in favor of its use, the young people with whom I relationship outside and inside the church do not use it... there is the forgetfulness of talking about responsibilities, the person is responsible for acquiring a disease [E.8; young black; 23 years]. On the other hand, white young people aged between 22 and 24 represented the expression sexuality (e1) as the word sex. When stimulus was added from the expression catholic religion (e2) virginity and family were evoked. Thus, the content of the interviews reinforces the heteronormative and Catholic discourse of sex for procreative purposes: (...) the church directs that the person marry and then have sex, we were created under this interpretation. The woman who was not a virgin should be stoned because she was taxed as a sinner [E. 13; young white; 19 years old]. There is a blockage, we are called to live chastity and we leave sexuality for after marriage [E.18; young white woman; 21 years].

The (e3), Aids, was associated with the words Africa, promiscuity, condom. When they were induced with (e4), catholic religion and AIDS, they issued words with religious connotation: guilt, faith, and empathy. The following speeches reinforce these evocations: I feel that the church has difficulty speaking clearly about these matters, even though it defends its values. I think people should protect and protect each other, in any way [E.9; young white woman; 18 years old].

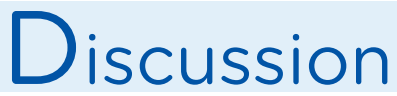

The Correspondence Factor Analysis highlighted the significant oppositions for the fixed variables sex, age group, and race/color. As for the origin of the participants (capital/metropolitan or interior), there 
was no significant opposition between the social representations of young people, which reinforces the notion that the internet, especially social networks, when used, the formation of membership groups, promote a "cybernetic culture" and, consequently, acculturate the groups. ${ }^{(5,6)}$ In these networked relationships, there is the formation of belonging groups that share ideas, beliefs, and religions, similar aspects of lives, favoring the production of social representations. In opposition to men, women include in their network of critical meanings as to how the Catholic Church treats sexuality, for it considers that free sexual practice is sinful, whose speeches are damning against those who exercise it. This reveals a consensus among them since most of them were inserted in higher education, having contact with the scientific knowledge, while their representations show dissent towards the men, who, for the most part, presented lower educational level than the women.

These new representations about sexuality, revealed by women differ from what is disseminated by the Catholic Church to those who practice it, and exposes a (re) thinking about sexuality that provides pleasure, does not cause guilt, at the same time, make them deviate from chastity, highlighting dissent in the representations of the group studied. Control exercised over bodies, called biopower, aims to repress sexuality through reified discourses permeated by prohibitions, denials, and social interventions, especially female sexuality. Biopower is adopted by moral norms of the Catholic religion, whose dogmas are strengthened in the name of God in order to make sex a consequence-laden $\sin .{ }^{(2,7)}$

The ideas opposed here to Catholic doctrines gain strength when it is proposed that young people can be good Catholics, but disagree with the hierarchical and imposing position of the Church. Even if they have the need and the desire to follow the norms of the church, all feel that freedom is necessary to distinguish what is essential to their faith. ${ }^{(2)}$ Both chastity and virginity, as well as practiced sex only matrimonially, constitute consensuses in the representational content, mainly in the social representations apprehended with Catholic men of the study group, since they think they are the most effective means to prevent $\mathrm{HIV}$, even if there is the availability of the condom. Also, they associated the conduct of each individual as the main cause of HIV infection, reinforcing the hegemonic representations about the forms of prevention and the cause for contamination with the virus (risk behaviors).

A study carried out with adolescents on the conceptions of homosexuality in their social context, they presented representations that are in line with those apprehended in the group of young Catholics, since the male homosexual practices are represented as a practice discriminated by the society, often associated with HIV infection. ${ }^{\left({ }^{8}\right)}$ This representational content about AIDS, expressed by both young Catholics and adolescents in the study cited has elements that subsidize the process of stigmatization of people who experience sexual and individual freedom, as a reflection of a macho, patriarchal society, embodied by a state that should be secular. ${ }^{(9)}$

The representation of fear may be associated with the idea of rejection, especially in social environments, the probability of suffering insults and discriminatory attitudes. In some studies the representation of fear was associated with misconceptions derived from the unconscious about AIDS, based on sexuality and death ${ }^{(10)}$ or by the impotence of many women in having difficulties negotiating with their partners to use condoms, hindering to protect against HIV infection. ${ }^{(10,11)}$ The representation of AIDS as a syndrome that is amenable to treatment is another consensus in the young Catholics of this study and has already been highlighted in other studies with several investigated groups such as adolescents, women, and people in the process of aging. ${ }^{(11,12)}$ Treatment is important for longevity with quality of life.

The words homosexuality and prostitution were high frequencies, revealing themselves in consensuses in the representational content of this study. This is corroborated in another study that analyzed the structuring elements of social representations about AIDS when the terms homosexuals and prostitutes 
had a discriminatory connotation to groups considered to be at risk. ${ }^{(13)}$ These representations that remain in the imaginary refer to this consensus on a stigma diffused and naturalized with the history of the beginning of the epidemic, which continues to permeate among young Catholics, possibly by traditional Catholic doctrine in the country. Another hegemonic representation of AIDS present with statistical significance in the words evoked by the young participants of this study was the association with Africa, possibly due to the relation to a knowledge spread in the 80's, still early in the epidemic, when it was propagated that the virus that caused AIDS was derived from the monkey and it was transmitted by the sexual practice of the human being with these primates in the African continent.

The idea that AIDS originated in Africa reveals the idea that this STI is "a disease of the other", which comes from poverty, i.e. only vulnerable and/or sexually free people are the most likely to be infected. This idea refers to the fact that AIDS is associated with sexual behaviors considered as deviant, such as bestiality, by groups from the poorest continent of the world, where social inequalities are more pronounced. ${ }^{(14)}$ This notion is part of the prejudice of Western society to society who considers her uncivilized for adopting unusual sexual practices, which is seen as deviant by the Catholic Church. This finding demonstrates another disagreement, since only part of the group associated HIV/AIDS as an infection related to socially marginalized people. In other words, everything that is in the logic of social and religious normality is considered abnormal, which reveals the social stigma about people who make up the population groups of sexual minorities. ${ }^{(15)}$

Therefore, it is not possible to understand social representations about sexuality and HIV/AIDS prevention in isolation, because it demands an understanding of how mental processes are socially constructed, in this sense, about social behaviors, such as sexual practices and roles played by men and women in society. ${ }^{(16)}$ It is thought that the consensus and dissent present in the representations of the young Catholics leads to the perception that there is as much influence of the Catholic religion as of the scientific knowledge about the representations of the faithful about sexuality, when some presented concepts of guilt and sin at times that did not follow the doctrines for sexual practices. However, others especially those who have access to higher education (mostly women) did not reveal guilt in their practices, even pointing to condoms as an important means of safe sex.

The conclusion of this study is that the representational consensus among young people is that sexual practice is pleasurable, yet it is condemned by the Catholic Church. As for AIDS, it is a consensus in their social representation that it is a preventable disease. In turn, dissent is evidenced when men represented the sexual practice outside what is proposed by the doctrine of the church as sinful (in this case outside marriage), showing respect for religion and women represented prejudice, while the church and members of it stigmatize those who choose freedom in the exercise of sexuality. As far as Aids is concerned, the dissent was perceptible when they objected to prejudice and irresponsibility, anchoring these representations in the stigma and social prejudice that many people have built about the disease; women, in turn, aimed at prevention and vulnerability, demonstrating in the social representation they have about AIDS a progressive vision in line with current scientific knowledge.

Also, in the consensus among men, there are sexist prejudices and stereotypes defended by Christian churches, such as Catholic, revealing influences on HIV prevention actions. Gender inequalities have been reinforced, with the propagation and reassertion of social constructions of sexuality and HIV among young people. Therefore, the contribution of this study lies in the fact that health professionals such as Nursing can propose educational activities on safe sex, based on social representations, which makes this study relevant, since knowledge of sexual rights is fundamental for the adoption of preventive practices. The study has its limitation in the low adherence of young people to data collection since the universe of social networks has numerous possibilities for recruiting participants. 


\section{References}

1. Durkheim E. As formas elementares da vida religiosa. Trad. Joaquim Pereira Neto. São Paulo: Paulinas; 1989.

2. Busin VM. Juventude, religião e ética sexual. São Paulo: Publicações Católicas pelo Direito de Decidir [Internet]. 2012 [cited 16 April 2018]. Available from: http://catolicas.org.br/wp-content/uploads/2014/07/LivroJuventudeReligiaoeEticaSexual-2ed.pdf

3. Santos EI, Gomes AMT. Vulnerability, empowerment and knowledge: nurses' memories and representations concerning care. Acta Paul. Enferm. 2013; 26(5):492-8.

4. Benelli SJ, Silva SIM. Subjetividade na Renovação Carismática Católica: Mecanismos de Funcionamento e de sua Produção. Psicol. Ciênc. Prof. 2016; 36(3):610-24.

5. Gouveia OMR, Matos AD, Schouten MJ. Social networks and quality of life of elderly persons: a review and critical analysis of literature. Rev. Bras. Geriatr. Gerontol. 2016; 19(6):1030-40.

6. Bezerra BG, Pimentel RL. Normativismo linguístico em redes sociais digitais: uma análise da fanpage língua portuguesa no facebook. Trab. Linguist. Apl. 2016; 55(3):731-55.

7. Ferreira AGN, Vieira NFC, Trasferetti JA, Galvão MTG, Gubert FA, Pinheiro PNC. Talking with adolescents from religious groups about hiv: challenges for nursing. Texto Contexto Enferm. 2013; 22(4):952-60.

8. Pereira CR, Torres ARR, Falcao L, Pereira AS. O papel de representações sociais sobre a natureza da homossexualidade na oposição ao casamento civil e à adoção por famílias homoafetivas. Psicol. Teor. Pesqui. 2013; 29(1):79-89.

9. Arraes CO, Palos MAP, Barbosa MA, Teles SA, Souza MM, Matos MA. Masculinity, vulnerability and prevention of STD/HIV/AIDS among male adolescents: social representations in a land reform settlement. Rev. Latino-Am. Enfermagem. 2013; 21(6):1266-73.

10. Rodrigues LAS, Paiva MS, Oliveira MS, Nóbrega SM. Vulnerability of women in common-law marriage to becoming infected with HIV/AIDS: a study of social representations. Rev. Esc. Enferm. USP. 2012; 46(2):349-55.

11. Silva Girlene Alves, Reis Valesca Nunes dos. Construindo caminhos de conhecimentos em HIV/Aids: mulheres em cena. Physis. 2012; 22(4):1439-1458.

12. Alexandre SG, Pereira MLD, Monte RS, Maia EG, Barbosa JS, Moura SKB. Representações sociais sobre sexualidade de mulheres no contexto da aids. Rev. RENE. 2013; 14(1):120-9.

13. Natividade JC, Camargo, BV. Elementos da representação social da AIDS agrupados em dimensões: uma técnica estrutural. Psicol. Teor. Pesqui. 2012; 28(2):193-6.

14. Vieira ACS, Head JF, Rocha MSG, Casimiro IMAPC. A epidemia de HIV/Aids e a ação do Estado. Diferenças entre Brasil, África do Sul e Moçambique. Rev. Katál. 2014; 17(2):196-206.

15. Santos AB, Shimizu HE, Merchan-Hamann E. Processo de formação das representações sociais sobre transexualidade dos profissionais de saúde: possíveis caminhos para superação do preconceito. Ciênc. Saúde Coletiva. 2014; 19(11):4545-54.

16. Santos EI, Oliveira JGAD. Social representations of nurses about professional autonomy and the use of technologies in the care of patients with wounds. Invest. Educ. Enferm. 2016; 34(2):387-95. 